\title{
John Moore: eighteenth century physician, bearleader and social observer
}

\author{
Andrew Steptoe DPhil DSc
}

J R Soc Med 2005;98:70-74

Many great figures in history began their working lives in medicine but moved away from the profession and excelled in other spheres; the philosopher John Locke, the poet John Keats, and the revolutionary Che Guevara are examples. Another group are those who used their medical training as a passport to a wider world that permitted their talents to flourish outside medicine. One such was John Moore, an eighteenth-century Scottish physician who in middle age seized the opportunity afforded by aristocratic connections to move from a comfortable but mundane medical practice in Glasgow to celebrity as a social observer and novelist.

\section{TWENTY YEARS IN MEDICINE}

John Moore was born in Stirling in 1729, the son of a Presbyterian minister. ${ }^{1}$ His father died in 1737 and the family moved to Glasgow, where he matriculated at the university when he was 12 years old. He was educated in the humanities, but in 1744 the celebrated medical educationalist William Cullen began to lecture on medicine and chemistry, and Moore was inspired. In that period, there were two routes to medical practice-education as a physician at the university leading to an MD, or apprenticeship as a surgeon-apothecary and licensing by the Faculty of Physicians and Surgeons. ${ }^{2}$ Moore was apprenticed to the firm of John Gordon in 1744. He was fortunate in this choice, since Gordon was a distinguished surgeon who had lectured in anatomy at the university as early as 1714 . He was described as a 'citizen of great and well merited popularity', and contributed to the design and management of the Town's Hospital, said to be the first hospital for the poor in Scotland. He was one of the generation of Scottish practitioners including Cullen and the Hunter brothers who helped revolutionize medical education and practice in the mid-18th century. The pioneering obstetrician William Smellie and the novelist Tobias Smollett had been earlier apprentices in the practice.

John Moore spent 3 years as an apprentice in Glasgow, but when he was 17 years old he decided to broaden his education by becoming surgeon's assistant to the Duke of Argyll's regiment, then active in Flanders during the War of

Department of Epidemiology and Public Health, University College London, 1-19 Torrington Place, London WC1E 6BT, UK the Austrian Succession. He spent the best part of a year at military hospitals near Maastricht, and also assisted the surgeon to the Coldstream Guards during action at Flushing and Breda. The peace in 1748 brought him to London where he attended lectures by William Hunter, before moving to Paris for a year. Here he was fortunate to be taken on as surgeon to the household of the Earl of Albermarle, the commander of the Coldstream Guards who was now British Ambassador. From Paris he wrote to William Cullen saying that he was principally studying surgery and midwifery, but still found time to entertain Tobias Smollett when he visited that city. Moore returned to Britain via London, where he attended a course in midwifery given by William Smellie. He was admitted to the Faculty of Physicians and Surgeons of Glasgow as a licensed surgeon and pharmacist on 3 September 1750. Thus by the age of 21 he had acquired an extensive education, complementing his general apprenticeship in Glasgow with specialist training in other centres, as well as making aristocratic connections that were later to prove invaluable. ${ }^{3}$

Moore was invited by John Gordon to become his partner in 1750. Gordon had been awarded an MD by Glasgow University, so he probably took on Moore to carry out the surgical side of the practice. They were soon joined by Thomas Hamilton, the future professor of botany and anatomy at the university, and between them developed a powerful and influential practice. They were well aware of international developments in medicine, practising variolation for the prevention of smallpox in the 1750s, and Moore took responsibility for the Town's Hospital. He continued in general practice for more than 20 years, married and had several children, and is mentioned affectionately in Smollett's last novel The Expedition of Humphry Clinker:

'We had the good fortune to be received into the house of $\mathrm{Mr}$ Moore, an eminent surgeon.... Mr Moore is a merry facetious companion, sensible and shrewd, with a considerable fund of humour; and his wife an agreeable woman, well bred, kind, and obliging.'

But Moore became bored with this life, and increasingly frustrated with the limited opportunities in Glasgow. As a 
product of the apprenticeship system, he had an uneasy relationship with the university, which dominated cultural life. He was proposed for a chair in midwifery in 1763 , but the suggestion was not taken up. He had literary ambitions, but these were frustrated when he was unable to obtain membership of the Glasgow Literary Society, also dominated by the university. Moore was an enlightenment liberal, and his views did not conform with the Calvinism of the merchants and ministers who dominated Glasgow society. The sense of exclusion was probably reinforced by his marriage. His wife Jean was the daughter of the late John Simpson, the professor of divinity at the university who had been suspended from teaching on the charge of heresy, his views being too liberal for their time. Later in life when ensconced in literary circles in London Moore 'could never think of Glasgow, when absent, without calling up a mental picture of Sunday morning in that city, and all the good families proceeding to Kirk looking as if they were going to the gallows and knew they richly deserved their fate'. ${ }^{4}$

\section{A GRAND TOUR}

His opportunity for change came in 1769 when, on Cullen's recommendation, he was asked to attend James George, the 7th Duke of Hamilton. The Hamiltons were the leading noble family in Scotland, and the 15-year-old Duke suffered from tuberculosis. He was the son of the celebrated beauty Elizabeth Gunning, who was 18 when she married the 6th Duke at midnight on St Valentine's Day in 1752, using the ring of a bed curtain as a wedding ring. James had become Duke at the age of 3, and his mother the Duchess had gone on to marry the future Duke of Argyll. The young Duke survived for only a few months, but Moore took great care with him and remembered the youth many years later with affection in his Medical Sketches of 1786:

'One case in particular, from various circumstances, made an indelible impression on my memory, the case of a youth of fifteen years of age, distinguished by more brilliant personal advantages and nobler endowments of the mind than I ever saw united to that period of life.'

James was succeeded by his younger brother Douglas, a difficult and impulsive youth who was then 13 years old. Moore had clearly recommended himself to the Duchess, since 3 years later she asked him to accompany the young Duke to the Continent. She had determined that her son would do well to undertake a European 'tour' and complete his education in Geneva. It was considered vital for such a rich young aristocrat to have a 'bearleader' who could exert some adult control while managing financial affairs, transport, housekeeping and education. Moore had finally been awarded an MD by Glasgow University, so could act as a physician to the Duke, and his familiarity with Paris and knowledge of languages would have also been advantageous. The Duke and Dr Moore were accompanied by Moore's 11-year-old son, the future general Sir John Moore, now remembered as the hero of Corunna (Figure 1). So at the age of 43, Moore left his wife and young family to set out on a tour through France, Switzerland, Germany, Austria and Italy that was to last 4 years and transform his life.

The party left England in early 1772 and the first 2 years were mostly spent in Geneva, followed by a leisurely journey through Germany to Berlin, then south through Vienna to Venice, Rome, Naples and Florence. John Moore had evidently decided to use the journey as a literary vehicle from the very start, and he published his $A$ View of Society and Manners in France, Switzerland and Germany in 1779, not long after their return to England. The Italian sequel $A$ View of Society and Manners in Italy was released in 1781. Both books were immediately successful and widely read. The first book had reached its ninth edition by 1790 and was also translated into German, while the Italian book was reprinted fourteen times over the next 20 years. ${ }^{5}$

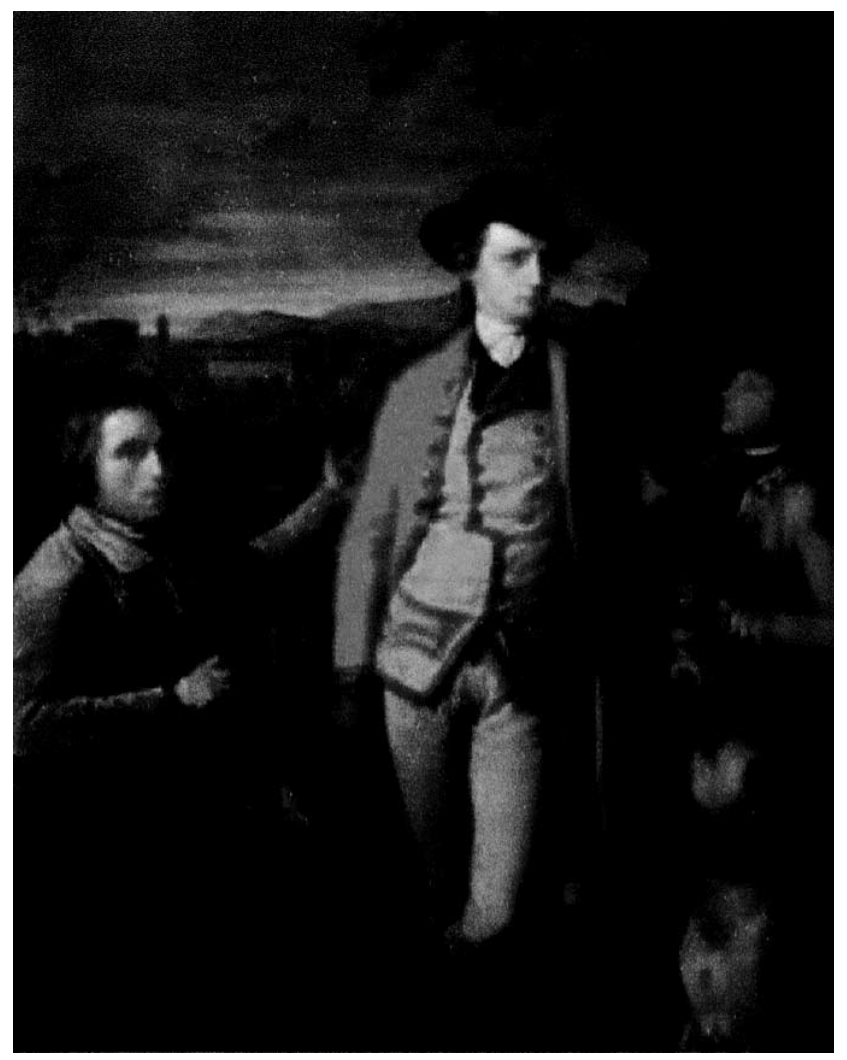

Figure 1 The 8th Duke of Hamilton with Dr John Moore and Ensign John Moore. [Gavin Hamilton (1723-98), oil on canvas]. The Duke is in the centre, Dr Moore to his right and the son to his left. A dog also sits to the Duke's left. In the background can be seen the Campo Vaccino, the Alban Hills and the Temple of Concord. [Reproduced by permission of the National Gallery of Scotland] 
There were several reasons for Moore's popularity as an author. Travel memoirs were in vogue, and numerous 18 th century literary figures described their journeys through Europe including William Beckford, Hester Lynch Piozzi (Mrs Thrale) and William Hazlitt. One of Moore's advantages was his social position. Most diarists were either restricted by their own social status from moving in the highest circles or were constrained by diplomatic protocol and rank from mixing freely across the spectrum of society. As companion to a member of the high nobility, Moore had an entrée to the most elevated society and was able to observe many of the leading figures of the day, including Frederick the Great of Prussia, the extraordinary reforming Emperor Joseph II, and Voltaire. At the same time, he could mingle with his social equals in the urban middle classes, gaining a wide perspective on society.

Second, he was primarily interested in the social customs and culture of the places he visited, rather than in the landscapes and antique artefacts that attracted writers steeped in early romanticism. His work is full of vivid anecdotes concerning the contrasting characteristics of society in different parts of Europe. He used descriptions of social behaviour to illustrate character, and his elegant turn of phrase anticipated later novelists such as Jane Austen. Here, for example, is a vignette of an attractive young widow in Paris:

'Madame de $\mathrm{M}$ - has some wit, more beauty, and a greater share of vivacity than of both. If there were a fourth degree of comparison, I should place her vanity there. She laughs a great deal, and she is in the right; for her teeth are remarkably fine. She talks very much, and in a loud and decisive tone of voice. This is not so judicious because her sentiments are not so brilliant as her teeth, and her voice is rather harsh. ... She is liked and followed by the men; this she owes to her beauty. She is not disliked by the women, which is probably owing to her foibles...

I found her at her toilette, in consultation with a general officer and two Abbés, concerning a new headdress which she had just invented. It was smart and fanciful; and, after a few corrections, received the sanction of those critics. They declared it to be a valuable discovery, and foretold that it would immediately become the general mode of Paris, and do immortal honour to the genius of Madame de $\mathrm{M}$ - . She wheeled from before the mirror, with an air of exaltation. "Allons, donc mais enfants_-à la gloire", cried she; and was proceeding to give orders for her equipage, when a servant entered, and informed her that Madame la Comtesse had accepted her invitation, and would certainly do herself the honour of dining with her.

I despair of giving you an idea of the sudden change which this message occasioned in the features of Madame de $\mathrm{M}$ - . Had she heard of the death of her father, or her only child, she could not have been more confounded. Is it possible (said she, with an accent of despair) that anyone could be such a beast! ... "Did you send to invite her for this day", said I? "Undoubtedly I did,', replied Madame de M. "That could be delayed no longer. She came to town last Saturday. I therefore sent her the politest message in the world, begging to have the honour of her company for this day, dinner, and behold the horrid woman (with a rudeness or ignorance of life without example) sends me word she will come." "'It is very shocking, indeed," said I, "that she should have misunderstood your kindness so prodigiously.' "Is it not," said she? "Could any mortal have expected so barbarous a return of civility?', ,

They travelled through Europe in most interesting times, as the beliefs of the Enlightenment were gradually diffusing through the Europe of the ancien régime. Moore inveighed against the social injustices of France, was horrified by the brutality of Prussian militarism, and caustic about the excesses of Catholic credulity in Bohemia and Italy. At the same time, he greatly admired the character of people in the different centres they visited, being particularly positive about the French and about society in Geneva and Vienna. Yet his strong sense that none of the countries they visited had a political system as desirable as the British constitutional monarchy would have been highly gratifying to his readers at home.

The tour brought many difficulties. Soon after they had arrived in Geneva, Dr Moore heard from his wife that the banking house in which they had invested their savings had collapsed, putting their future in jeopardy. He also had his hands full with managing the Duke, who was handsome and amiable but at the same time impulsive and changeable. He described the Duke in the following terms:

'He has many amenable qualities and excellent understanding. ... His foible is a love of show and an uncontrollable desire for every new object, which however becomes insipid as soon as acquired. ... He is sometimes peevish yet his temper is not bad, and his dispositions are much better than his temper. He cannot bear contradiction, and is subject to violent gusts of passion but is incapable of harbouring malice or revenge... The Duke is fitted for the best company in every sense of the word-among such he is polite, modest and judicious: But with the other class, his behaviour may be construed as self-sufficient, arrogant, and capricious.' 6

Early on, there was a potentially disastrous incident when the Duke of Hamilton was fencing in fun with young 
John Moore, who was 5 years his junior. The boy was accidentally pierced with the sword, but it was not a dangerous wound and Dr Moore's kind reassurance of the Duke evidently cemented their friendship. Yet he was constantly required to restrain the Duke's extravagance, mend social connections damaged by the Duke's impulsive and arrogant behaviour, and extricate his employer from romantic scrapes. He narrowly escaped dismissal by the Duchess of Argyll when she learned that he had acted as midwife to two English ladies in Geneva, and needed all his diplomacy to justify himself. Expenses mounted, so that by the time they arrived in Italy in late 1775, the party included two carriages, ten horses, four footmen in livery, a valet and two other servants. Nevertheless, Moore remained good friends with the Duke and his mother the Duchess after the party returned to England, and the Hamiltons sponsored young John Moore's army career and entry into Parliament when he was only 23 years old.

\section{LITERARY LIFE}

Moore had decided that he could not face returning to medical practice in Glasgow when the tour was over. As he put it in an unpublished memoir, he had 'no great taste for the manners of the inhabitants of Glasgow' and had 'taken a great dislike to return to the profession of medicine-I preferred a moderate income in any other respectable way to the greatness that could be acquired by visiting sick people. ... I had uneasiness and disgust in that of rolling through the streets from morning from one disease to another'. ${ }^{3}$ The family therefore moved to London, where literary life took up more and more of his time. His travel books were followed by the Medical Sketches of 1786 and three novels. The first of these, Zeluco, was published in 1786 and was particularly successful. The story concerned a Sicilian who was brought up without proper control; his first act was to squeeze a pet sparrow to death, and his career went from bad to worse. Moore warned readers that 'tracing the windings of vice and delineating the disgusting features of villainy are unpleasant tasks, and some people cannot bear to contemplate such a picture'. The book was nevertheless influential in the early Romantic period, and was cited by Byron as an inspiration for Child Harolde's Pilgrimage.

The Duke of Hamilton meanwhile continued on his impulsive way. Less than a year after returning to England he married Elizabeth Burrell, the daughter of a 'private gentleman', much against his mother's wishes. Described as one of the handsomest men of his day, the Duke gradually gave way to dissipation. He was fond of boxing and low company, and gave dinners to hackney coachmen. He was cited in the divorce of the Earl of Eglington from his wife Frances, who gave birth to a daughter soon after the separation, thought to be the Duke's child. Curiously, Frances Eglington went on to marry Moore's fourth son Frank, so became part of their family. The Duke was himself divorced by his wife in 1794, and died 5 years later at the age of 43 . He left all his property to an illegitimate daughter, and the next Duke (his cousin) had to buy back the pictures and furniture of Hamilton Palace.

In London, John Moore at last joined the literary circles to which he had so long aspired. He met Dr Johnson, was friendly with Mrs Piozzi, Edmund Burke and Reynolds, and was a patron of Robert Burns. He was painted by Thomas Lawrence, and had a wide acquaintance. This activity all took him further and further from medicine, but it is likely that another reason for his change of career was a realization that his treatments were not effective. He wrote in his Medical Sketches 'It is astonishing how exceeding apt medical practitioners of every denomination are to impute to drugs that salutary effect which proceeds from the universal influence of another cause...this constant tendency in nature to overcome disease... is acknowledged by all candid and discerning practitioners to have a powerful influence in the cure of diseases'.

His political views had always been liberal. In the memoirs of his Italian journey he had stated 'Let the princes be distinguished by splendour and magnificence; let the great and the rich have their luxuries; but in the name of humanity, let the poor, who are willing to labour, have food in abundance to satisfy the cravings of nature, and raiment to defend them from the inclemencies of the weather! If their governors, whether from weakness or neglect, do not supply them with these, they certainly have a right to help themselves'. He became a fierce supporter of the early phases of the French Revolution. His enthusiasm is all the more remarkable since he was an established figure in his early 60 s, not a young revolutionary. This partiality led to his association with the Earl of Lauderdale, the radical young aristocrat who founded the Society of the Friends of the People in 1792. The Earl had recently been involved in two affairs of honour, one with the Duke of Richmond, and the second with Benedict Arnold, son of the American military turncoat, and it was thought prudent that he leave the country for a period. Once again, Moore's medical training proved an asset, and he took up the role of companion-physician, travelling with the Earl through France in 1792.

John Moore left for France as an enthusiast for the Revolution but returned much chastened. He witnessed the attack on the Tuileries on 10 August, the hearings of the Legislative Assembly attended by the King, and the terrible carnage of the September massacres. He saw how the Assembly was disrupted through intimidation and physical threats to deputies, leading to the victory of terrorist cliques. He felt increasing sympathy for the Royal Family as 
he witnessed the replacement of one tyranny by another, and believed the King to be not vicious but a victim of circumstances. When his A Journal of a Residence in France from the beginning of August to the middle of December 1792 appeared in 1793, it was by no means the paean to revolution that many had expected. Critics were surprised at his change of heart, stating 'Many have been afraid to take up the present publication, lest they meet in it those opinions which are now become obnoxious', and 'Some reflections and sentiments occur in this volume, which appear to be inconsistent with ideas that have formerly been entertained by Dr Moore'. ${ }^{7}$ He now regarded the French people as fickle and bloodthirsty, and became a reluctant supporter of Britain's war against the Directory in later years.

Moore published one more major book, his ambitious View of the Causes and Progress of the French Revolution in 1795, based on his own reading and interviews with French royalists living in England. He lived on until 1802, and when he died left the substantial fortune of $£ 30000$. His children went on to successful careers. His son John became one of Europe's most admired generals before dying heroically at Corunna in 1809. Another son was admiral Sir Graham Moore, Frank was a diplomat, and James followed his father as a physician and writer. This progress from modest beginnings all stemmed from training in medicine, and although John Moore became disenchanted with practice, he must have recognised its worth as a route to success.

\section{REFERENCES}

1 Anderson J. The Works of John Moore, M.D. with Memoirs of his Life and Writings, 7 Vols. Edinburgh: Stirling \& Slade, 1820

2 Geyer-Kordesch J, Macdonald F. Physicians and Surgeons in Glasgow. The History of the Physician and Surgeon of Glasgow, 1858-1999. London: Hambledon Press, 1999

3 Fulton HJ. John Moore, the medical profession and the Glasgow enlightenment. In: Hook A, Sher RB, eds. The Glasgow Enlightenment. East Lothian: Tuckwell Press, 1995:176-89

4 Oman C. Sir John Moore. London: Hodder \& Stoughton, 1953

5 Fulton HJ. An eighteenth-century best-seller. Pap Bibliograph Soc America 1972;66:428-33

6 Campbell JDS. Intimate Society Letters of the Eighteenth Century. London: Stanley Paul, 1910

7 Fulton HJ. Disillusionment with the French Revolution: the case of the Scottish physician John Moore. Stud Scottish Lit 1985;23:46-65 